\title{
Historical perspectives on pastoralism and land tenure transformation in Ngamiland, Botswana: What are the policy and institutional lessons?
}

\author{
Lenyeletse Vincent Basupi", Claire Helen Quinn and Andrew John Dougill
}

\begin{abstract}
Pastoral societies in dryland Africa continue to face changes to their systems. These systems are influenced by a range of historical factors, but little use is made of this information to design policies that suit pastoralists' landscapes. This article provides a synthesis of historical perspectives on pastoral land use and tenure transformations in Ngamiland, south of the Okavango Delta, Botswana. Little documentation of herders' historical perspectives exists and less is known about how past experiences can be applied to sustainable pastoralism policies. In this article, current land use pressing issues are examined and analysed within the context of past experiences. We use a series of oral histories with key informants, focus group discussions, expert interviews and rangeland field observations. Results show that Nagamiland's pastoral landscape has been shaped by a variety of factors: livestock diseases, human-wildlife conflicts, droughts, land tenure transformations associated with rangeland policies and the pastoral identity of the Ovaherero/Ovambanderu ethnic groups. Pastoralists have followed unique trajectories, specific to their rangeland conditions and socio-cultural context. Resilience to climate shocks and diseases has been weakened by inequitable patterns of control over rangeland resources. We recommend institutional diversity such that from experiences of the past, lessons can be drawn of processes and institutions required for pastoralism policies targeted pastoralists' adaptations. Using pastoralists to provide information, especially in the area of indigenous knowledge, strategies can be developed to link conservation of wildlife and rangelands with pastoral production by developing ecologically sensitive low-volume tourism that pastoral communities can tap to diversify their livelihoods.
\end{abstract}

Keywords: Environmental histories, Livestock mobility, Institutions, Rangeland policy, Vulnerability, Okavango Delta

\section{Introduction}

Policy debates on pastoralism have given increasing attention to issues of communal area development and management (Rohde et al. 2006; Behnke 1987). Many policies have been attempted in African countries to increase livestock production in communal areas while at the same time maintaining the forage quality of the range (Mwangi 2009; Rass 2006; Fratkin 1997). In this effort, traditional pastoralism has been commonly viewed as unproductive and directly responsible for rangeland degradation (Oba 2013).

\footnotetext{
* Correspondence: vbasupi@gmail.com; eelvb@leeds.ac.uk Sustainability Research Institute, School of Earth and Environment, University of Leeds, Leeds LS2 9JT, UK
}

Pastoral societies and their use of rangelands have been shaped by a range of historical factors, but little use is made of this information to make policies that suit pastoralists' landscapes and local knowledge bases (Fernandez-Gimenez 2006). Research on pastoralism has given increasing recognition and support to traditional pastoralism, livestock spatial mobility (Kitchell et al. 2014; Scoones 1995) and to rights of pastoral people to control and manage their grazing territories (Adriansen and Nielsen 2002; Swift 1991). It is argued that flexible livestock mobility reduces pastoralists' vulnerability to climate change and the likelihood of livestock-induced rangeland degradation (Brottem et al. 2014). However, in most sub-Saharan African countries, such recognition has 
not yet translated into the protection and maintenance of traditional pastoralism of flexible mobility-based systems (Basupi et al. 2017; Kitchell et al. 2014).

The history of land tenure transformation in Africa shows a prevailing trend whereby the erosion of collectively held communal grazing lands and natural resources under customary tenure is being hastened by policies that support privatisation of formally communal grazing lands (Rohde et al. 2006). Intensified means of livestock production through privatisation are often incompatible with a mobility strategy, especially when privatised land tenures prompt pasture fragmentation and underpin ecosystem service diversity losses. The livelihood prospects of pastoralists remaining in communal grazing areas are hence potentially challenged by higher vulnerability to livestock disease incidences, climate variability and land degradation. Livestock mobility in resource-scarce environments is critical for reducing the concentration of livestock in smaller territories, thus contributing to sustainable land management (SLM) (Moritz et al. 2013). Many governments still face the challenge of developing the right institutional frameworks and strategies that address pastoral development while ensuring SLM (Notenbaert et al. 2012). Historical perspectives can help increase our understanding of pastoral areas, thus providing a reference point for assessing current pressing issues (Swetnam et al. 1999).

Botswana represents a case study country that has focused agricultural development policy on communal land privatisation (Rohde et al. 2006; White 1993) and fencing linked to animal health policies (McGahey 2011). The ranching system was formally introduced in 1975 through the Tribal Grazing Land Policy (TGLP) as an option to promote the conservation and sustainability of dryland ecosystems (Magole 2009; RoB 1975). It was argued under TGLP that land could be used to greater advantage if farmers had an incentive to gain control over grazing areas, exclude others by fencing their land and be able to obtain direct benefits through investments and production of quality beef. TGLP targeted land that was believed to be unused. This was later extended by the National Policy on Agricultural Development (NPAD) of 1991 through intensification and expansion of TGLP objectives into all communal areas. Through NPAD, ranches would not be limited to certain 'unused' areas; instead, demarcation of ranches would depend on the number of cattle, the availability of land and its carrying capacity, and individuals could apply to fence areas within the vicinity of their boreholes (RoB 1991). The relevance of the ranching system in rangeland resource management and its principal assumptions has been hotly debated in the pastoralism literature (Rohde et al. 2006; Dougill et al. 1999; Ellis and Swift 1988). What is limited in the academic debate is a detailed understanding of the historical evolution of pastoral landscapes and land use patterns, and how historical perspectives are embedded within the policy processes. Less is understood about the interlinkages between multiple historical factors and evolution of issues in shaping pastoralists' landscapes and land use patterns. Such lack of empirical analyses on the historical evolution of issues for communal rangeland areas affects the sustainability of current rangeland policies. To understand current pastoral land use patterns and policies, a historical perspective is useful since it can help uncover the evolution of social and environmental challenges in rangelands (FernandezGimenez 2006). Our findings rest on enhancing understanding of pastoral social-ecological systems from a historical analysis point of view so as to inform policy strategies to improve pastoral livelihoods and manage pastoral landscapes.

The paper aims to provide a synthesis of historical perspectives on pastoral land use and tenure transformations in Ngamiland, south of the Okavango Delta, Botswana. The study's objectives are to (1) identify historical occurrences that influenced pastoralists' land use patterns and determine their impact on the current form of land use, (2) explore pastoral communities' perspectives on current land use and rangeland access and (3) explore the relevance of historical perspectives to lessons regarding policy processes, institutions and strategies for SLM in pastoral landscapes.

\section{Study area}

Ngamiland District is situated in north-western Botswana (Figure 1). It is home to one of the world's largest inland deltas: the Okavango. Land is broadly zoned into different uses: communal areas, National Parks, Game Reserves, ranches, wetlands, controlled hunting areas and wildlife conservation areas (operated as tourism concessions) (DoL 2009). Flow over the delta extends over a great area feeding into the Thamalakane, Kunyere, Nhabe and Boteti rivers. The hydrological system of the district has a significant influence on livestock grazing, particularly around Lake Ngami. The climate is sub-tropical (semi-arid), with distinct hot, wet summers and cold, dry winters. The study area is dominated by open low shrubs and tree savannas. Livestock rearing is concentrated along the permanent open water sources at the fringes of the Okavango Delta and around Lake Ngami.

Table 1 shows human and livestock numbers in the study villages.

\section{Methods}

A mixed-method approach was used; oral histories, focus group discussions and expert interviews in seven study villages; Sehithwa, Toteng, Bodibeng, Bothatogo, Kareng, Semboyo and Makakung (Figure 1). The villages were selected on the basis that the majority of residents 


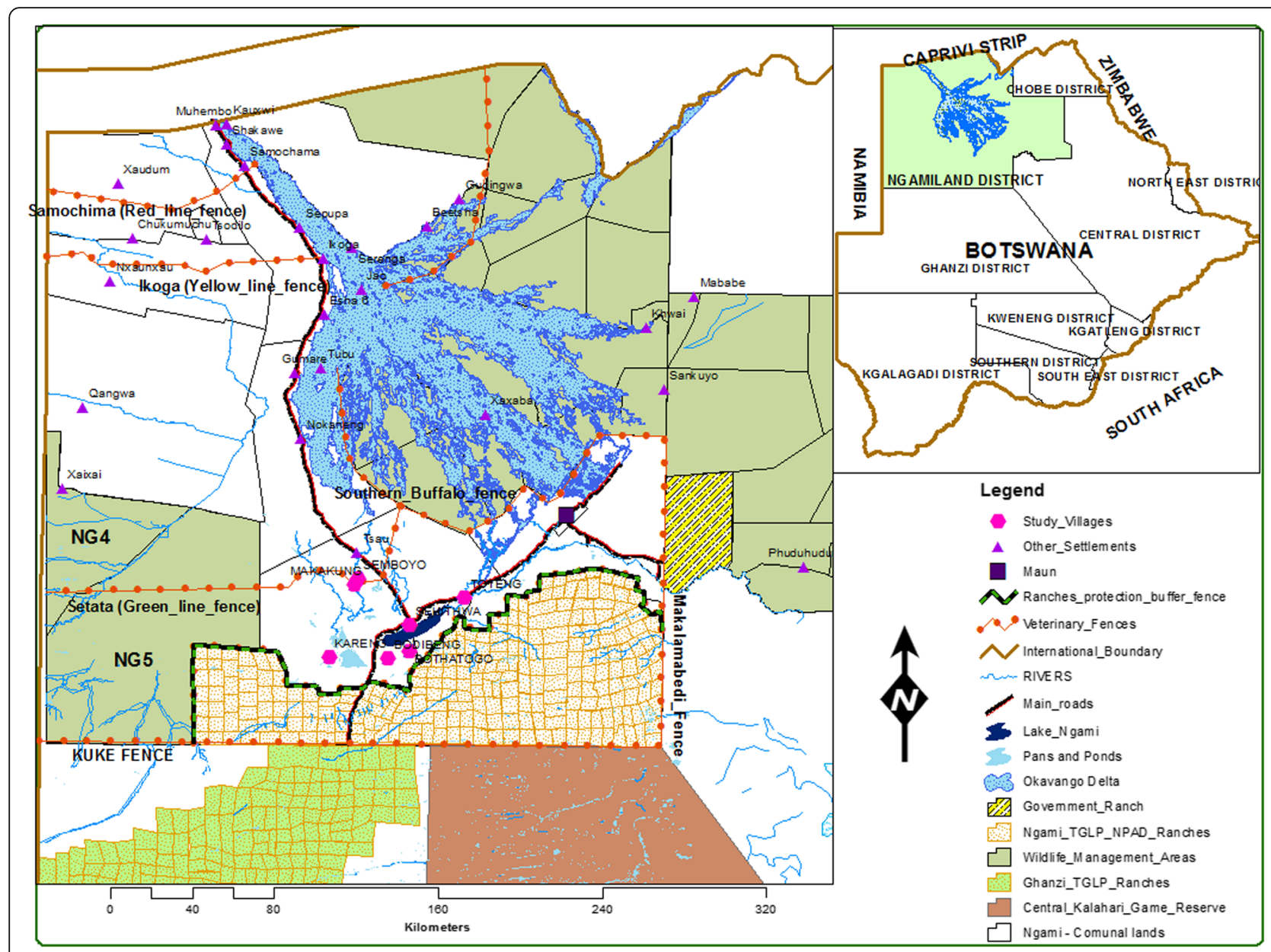

Figure 1 Ngamiland study area. Source: authors' data sources: Tawana Land Board, Ministry of Agriculture

practise agro-pastoralism and rely heavily on livestock, particularly cattle, as the largest investment in agricultural assets and livelihoods.

\section{Oral histories}

An enquiry into the pastoral history of the area was conducted through oral histories to collect information from a wide range of people with experience of pastoral systems, especially around issues of land tenure transformation and historical occurrences that influenced pastoral land use patterns. Through historical accounts, we reconstruct how pastoralism, land use and tenure has changed over time as well as establish past land management practices and historical timelines of major events influencing land use. The selection of participants was based on purposive sampling based on their extensive knowledge and experience. In order to find participants, we established rapport with members of the pastoral community through visits and interactions. We visited cattle posts and examined watering points. We also helped some pastoralists in

Table 1 Human and livestock numbers in the study villages

\begin{tabular}{llllll}
\hline Village & Human population & Cattle population & Goat population & Sheep population & Donkeys and horses \\
\hline Sehithwa & 2,748 & 16,635 & 1,712 & 471 & 953 \\
Toteng & 909 & 24,828 & 3,743 & 1,015 & 1,444 \\
Bodibeng/Bothatogo & 1,333 & 26,842 & 4,070 & 1,313 & 1,816 \\
Kareng & 1,259 & 37,722 & 4,760 & 707 & 1,850 \\
Semboyo/Makakung & 691 & 19,986 & 3,484 & 632 & 1,299 \\
Total & 6,249 & 126,013 & 17,769 & 4,138 & 7,362
\end{tabular}

Data source: Central Statistics Office, 2011, Department of Veterinary Services, 2016 
transporting fodder to calves and participated in foot and mouth disease (FMD) (Aphthae epizooticae) vaccinations. Through such visits, we gained insights about the pastoral systems and explained our research to potential respondents. Potential respondents were identified, and appointments for detailed in-depth interviews made. We also visited and held talks with members of farmers' committees and farmers' associations who suggested further potential respondents. Most informants were older men and women, mostly of the Ovambanderu and Ovaherero tribes who were young during the 1940s to 1960s and had witnessed most of the transformations in communal land in Ngamiland since the era of the tsetse fly epidemic (1960s). Some of the histories narrated were passed down through generations. A total of 26 informants were sampled from across the study villages.

\section{Focus group discussions and expert interviews}

In order to gain insights into the current land use issues, nine focus group discussions ( 8 to 14 participants per focus group) were held as follows: Semboyo $(n=9$ attendees), Makakung $(n=12)$, Bothatogo $(n=10)$, Bodibeng $(n=8)$, Toteng $(n=9)$, Sehithwa $(n=8)$ and Kareng $(n=6)$. Data from focus groups was used to corroborate information from professional informants and oral histories. Focus groups targeted different stakeholders and groups in the community, especially pastoralists with experience in communal areas, members of the communal farmers' associations and farmers' committees. One of the focus groups targeted only women ( $n=14$ participants; agro-pastoralists, members of farmers' committees drawn from across the lake villages: Sehithwa, Bodibeng, Toteng, and Bothatogo) in order to incorporate divergent views and also to avoid a situation whereby influential male members of a group dictate the discussions. Another focus group targeted young farmers $(n=14$ young participants who are engaged in pastoral farming and those that were active in community projects; drawn from across the study villages). This was meant to solicit views and perceptions of youth groups concerning issues of pastoral land use and rangeland access. Interviews were also held with government officials in the Ministry of Agriculture, Department of Veterinary Services $(n=4)$; Tawana Land Board, Division of Land Use $(n=2)$; District Land Use Planning Unit $(n=$ 2 ); Department of Environmental affairs $(n=2)$; National Development Bank (NDB) $(n=1)$; Department of Wildlife and National Parks $(n=4)$; and Department of Forestry and Range Resources $(n=2)$. The purpose of these interviews was to get an in-depth understanding of pastoralists' issues, perspectives on current land use, pastoralism and policy issues from professional experts.

\section{Data analysis}

Oral history data were analysed based on the MillerRosser et al. (2009) analysis approach. This involved: (i) Testimonies of each respondent were transcribed using Microsoft Word and interpreted to derive meaning from each historic account using a coding framework (Table 2); (ii) searching for commonalities: extrapolation of common themes from each narrative -each individual testimony was cross-validated and inconsistencies identified; (iii) writing the narrative - the interpretation of all participants' testimonies was constructed into one story per theme emanating from the discussion (Miller-Rosser et al. 2009).

Historical literature was used to validate and contextualise participants' accounts. Findings from oral histories were directly compared to historical literature at University of Botswana library - Botswana Collection and Botswana National Archives. The following were used: History of Ngamiland (Tlou 1985), Herero/Mbanderu history (Gewald 2002; Almagor 1980) and History of the Basarwa ${ }^{3}$ (Dziewiecka 2008). Relevant quotations were used to explain and clarify data (Patton 1990).

Other qualitative data from focus groups were transcribed and analysed using content analysis to identify the main themes or issues emerging from the discussions (Adam et al. 2015). The development of themes involving the orderly and continuous search for patterns was used to produce full descriptions that shed light on the issues under investigation (Gale et al. 2013).

\section{Results}

This section presents the study's results based on the objectives. First, we give an account of major historical occurrences affecting pastoralism and pastoral land use patterns in Ngamiland since the 1920s through to the present. Secondly, drawing from data gathered from focus group and expert interviews, we discuss local pastoralists' perspectives on current land use and how rangeland privatisation has affected pastoral land use and land tenure. Finally, the study offers insights on how historical perspectives can be used to inform policy on sustainable pastoralism. Table 2 is a summary of results of oral histories and focus group discussions, and the four global themes have been used to organise the findings section.

\section{Historical land use practices Ethnic pastoral groups}

In Ngamiland south of the Okavango Delta, the Ovaherero and Ovambanderu ethnic groups are the dominant communities. Pastoralism is their main livelihood activity, and their transhumant system has developed under variable geopolitical, social and climatic conditions (Tlou 1985). Oral histories detail that Ovaherero 


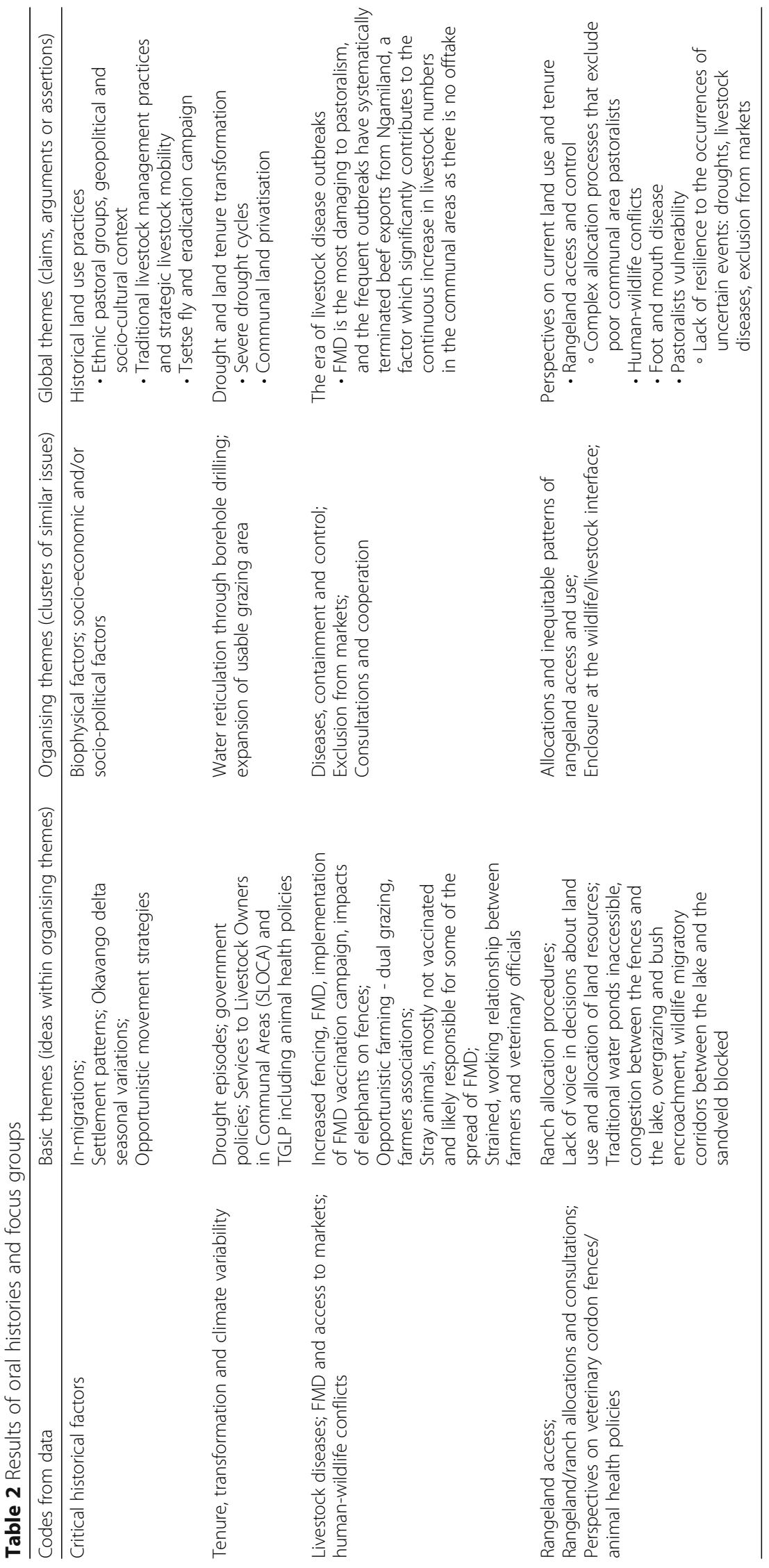


and Ovambanderu pastoral communities in Ngamiland have their origin in Namibia. Historically, people who speak dialects of the Bantu language Otjiherero belong to the three broad divisions within the Otjiherero-speaking society in Namibia: the Ovaherero, the Ovambanderu and the Ovahimba. These people share a number of cultural elements that relate to social organisation, preferred economy, epistemology, and spatio-political organisation. The Ovambanderu and Ovaherero speak the same language, and both live a pastoral way of life and practise the same pattern of land and livestock management (Almagor 1980). In spite of these similarities, they have maintained two separate identities, divided by an ethnic boundary. Many of these people fled to Ngamiland during the German-Herero colonial war of 1904 to 1914 (Tlou 1985). During that period, Kgosi Sekgoma Letsholathebe (Kgosi translates as Chief or King in Setswana) ruled the Tawana Kingdom in Ngamiland (Gewald 2002; Tlou 1985). In order to establish a strong base for the Tawana Kingdom, Sekgoma allowed the Ovambanderu and Ovaherero groups to become full members of the Tawana Kingdom yet retain their own identity, speaking their own language and continuing their pastoral way of life (Tlou 1985). Through the practice of mafisa, ${ }^{1}$ and through the royal cattle loans provided by Kgosi Sekgoma, the Otjiherero refugees were able to re-establish themselves as wealthy cattle owners within a generation (Gewald 2002).

\section{Ovambanderu/Ovaherero settlement patterns}

Oral history testimonies of pastoralists interviewed in Sehithwa, Bothatogo, Bodibeng and Toteng suggest that Ovambanderu pastoralists have been expanding their territories around Lake Ngami, especially along the western margin of the Delta, since the early 1930s. The number of settlements in the dry Kalahari sandveld remained low until the 1950s/1960s outbreak of the tsetse fly epidemic after which settlements in the sandveld increased. Most cited stock losses due to diseases alongside the Okavango swamps as reasons for moving inland.

Information gathered from key informants and focus groups suggest that the area stretching from the southern and eastern shores of Lake Ngami to Kuke cordon fence (Figure 1) was a Basarwa ${ }^{3}$ territory. The settlements around the Khwebe hills were a well-known area for the Basarwa, ${ }^{3}$ who had relatives in the adjacent Central Kalahari Game Reserve (CKGR). The inhabitants of the Khwebe hills, otherwise known as the Kwe (Kwe meaning people and 'Khwebe' means place of people), were nomadic hunter-gatherers (Dziewiecka 2008). Ngamiland was seen as being rich in grasslands, woods and water, especially during the wet season, and Okavango floods attracted a lot of gam, making it a favourable place for the Kwe, '...the Kwe were generally carefree people..., they knew the land...faced with the worst drought in the 1960s, we moved further south until we reached the Khwebe hills (Figure 1), we found the Kwe, ...they showed us spring water in the hill...the land was good, some of our animals survived the harsh drought...' (Oral history data, 82-year-old Ovambanderu pastoralist, Bodibeng, 2015). Respondents reported that, following the arrival of the Ovambanderu pastoralists, the Kwe's mobility started to decrease and temporary encampments were gradually replaced with semi-permanent settlements on cattle posts. Some were employed by the encroaching Ovambanderu pastoralists and were paid a calf or two a year for their service, enabling them to accrue some cattle of their own. The area of Khwebe hills was demarcated as ranches under the TGLP and is now inaccessible by the Basarwa ${ }^{3}$ of Kwe or Ovambanderu pastoralists. The remnants of the Kwe people can now be found in Somelo, a Remote Area Dweller (RAD) ${ }^{4}$ settlement $70 \mathrm{~km}$ south-east of Maun town.

\section{Traditional pastoral management practices and strategic mobility}

Oral history narratives suggest that before the land tenure transformation, the Ovaherero and Ovambanderu of Lake Ngami viewed their grazing landscapes as an interconnected ecological zone, divided into neighbouring localities and grazing grounds for different seasons. Herding practices involved following seasonal transhumant patterns between areas around the delta in the dry season and sandveld grasslands in the wet season. It was important that grazing areas had sufficient resting time from the previous grazing cycle. The grazing system was enforced by the chief (traditional leader or Omuhona). Clans controlled different grazing areas and cattle post (ofarama or kombanda) areas established around large pans (macha or ovikango). If pastoralists did not follow the grazing patterns, fines were imposed by the chief and a council of elders in the clan known as land overseers. These transhumant pastoralists adopted an approach involving controlled but flexible movements away from the delta to the sandveld grasslands during the wet seasons, including reciprocal access agreements with neighbouring clans in order to respond to environmental variability. Table 3 summarises factors that influenced the Ovambanderu/Ovaherero temporary migrations, while Figure 2 shows pastoralists' conceptualisation of settlements around Lake Ngami and their adjacent rainy season pastures before fences and land subdivisions. The pans were normally associated with the rainy season because of the water that is collected. Once the rainy season started, small groups from individual compounds left their settlements and moved away from the lake in search of better pastures. They spent the entire rainy season within a single pasture area, around a specific pan, returning only when water sources had dried up. Each settlement had their own pans which they 
Table 3 Factors that influenced pastoralist temporary migrations before the land tenure transformation (Focus group discussion data, 2015)

\begin{tabular}{ll}
\hline Factor influencing strategic mobility & Justification \\
\hline Fluctuations in forage and water availability & Take advantage of resources found in different places in different seasons such as water \\
& in the sandveld pans and surrounding grasslands \\
& Allow grass to recover around Lake Ngami and Okavango riparian woodlands which \\
& were typically dry season grazing areas
\end{tabular}

The number of livestock herds owned

In order to take advantage of a diversity of ecosystems, those with larger herds utilised herd splitting and grouping as a strategy to cope with drought or climatic variations; lactating, pregnant cows and calves were kept separate and closer to settlements; the males and non-producing females could travel long distances without water and were kept at distant encampments moving from one pan/ovikango to another in search of better grazing and water

The seasonality of the natural regimes; rainfall, Okavango delta seasonal flooding

Skill level of the herder and labour availability
Reduce the probability of crop damage and resultant fines because floodplains were used by agro-pastoralists for flood recession agriculture known as molapo farming or ondondu farming (molapo means river in Setswana and ondondu means river in Otjiherero) Avoid the moist conditions of the delta which is often a breeding ground for insects and disease outbreaks. Such movement strategies were used to combat the spread of FMD or the nagana disease associated with the tsetse fly

During rainy season, wild buffaloes move from the core of the delta to the peripheral areas of the delta, hence increasing the possibility of mixing with cattle. By moving away to the sandveld, such mixing was avoided; hence, pastoralists argue that outbreaks of FMD were low and manageable

Knowledge of the herder was paramount in exploiting the different characteristics of the range, determining niche specialisation of herds and herd splitting for herds' survival during prolonged dry season and drought periods

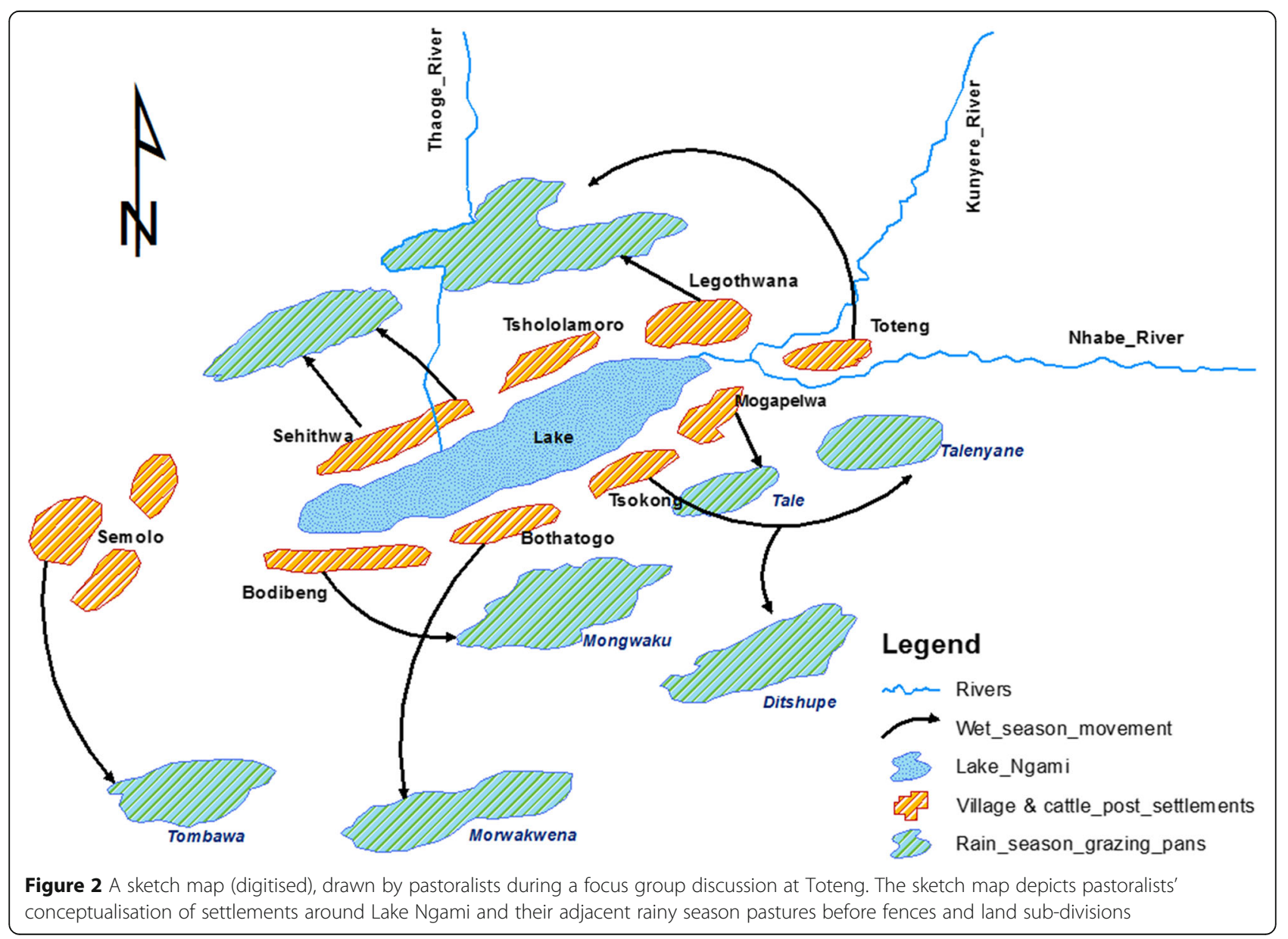


controlled and regulated through reciprocal access agreements and social relations.

\section{0 s to 1960 s - the tsetse fly epidemic and eradication campaign}

Respondents reported that from the mid-1920s to late 1960 s, they were confronted with frequent outbreaks of sleeping sickness and nagana disease caused by the tsetse fly. The tsetse epidemic played a critical role in settlements and migration patterns of different ethnic groups around the Okavango Delta. To flee the ravages of the tsetse fly, people moved out into the sandveld with their livestock. Riverine lifestyles were disrupted and new settlements emerged. According to local informants in Sehithwa and Toteng, neither the colonial government nor the Tawana authorities were able to handle the problem. The only alternative for pastoralists was to move to unaffected areas in the sandveld. It was only in the mid-1960s under Sir Seretse Khama (Botswana's first president from 1966 to 1980) that the tsetse was effectively controlled. According to Tlou (1985), the tsetse fly had the most devastating effects on the spatial distribution of the Ngamiland population because, unlike mosquitoborne malaria, the tsetse fly-borne diseases, sleeping sickness (trypanosomiasis) and nagana, afflicted both humans and cattle alike. Settlements such as Semboyo and Makakung emerged during this period as the Ovaherero migrated further into the sandveld.

\section{Drought and land tenure transformation 1960 s to 1980 s severe drought cycles}

This period was characterised by recurrent droughts owing to successive seasons of poor rainfall. Respondents reported that the impact of the $1965 / 1966$ drought was so significant that by the middle of the drought period, grazing fodder was almost non-existent and many cattle died. Weaker and severely emaciated cows were kept near homesteads and fed on branch leaves pruned from trees around the Okavango Delta. Some calves were slaughtered so as to reduce stress on their mothers. There was a massive movement of animals to areas with water, '...every drought in Ngamiland brought other pastoralists from different parts of the district to Lake Ngami, which even up to now has the highest concentration of cattle in Ngamiland' (Oral history data, 69-year-old Mbanderu pastoralist, Sehithwa, 2015). However, respondents reported that little water collected in the pans (macha) and the lagoons dried up. Some pastoralists moved as far as the Khwebe hills in the current Hainaveld ranch area. It was also during this period (1975) that the government introduced the TGLP to curb the problems of overgrazing that were reported to be commonplace in the communal grazing lands, particularly in the eastern hardveld of Botswana. So this marked the start of an era of tenure transformations.
Another severe drought hit the country in 1982. Participants in both focus groups and oral histories recalled that in the midst of this drought, the government introduced the programme Services to Livestock Owners in Communal Areas (SLOCA), a grant scheme designed to help small-scale pastoralists in the communal areas with water reticulation through borehole drilling and construction of drift fences. Some pastoralists were able to drill boreholes through this scheme, and as a result, new lands in the dry Kalahari sandveld were opened up for grazing. However, some Ovambanderu and Ovaherero pastoralists reported that they were reluctant to invest in borehole drilling because they still had hopes of going back to Namibia: '...some pastoralists thought then, it will be futile to do so, drilling a borehole is expensive and again you cannot carry a borehole to Namibia' (Oral history data, 74-year-old Ovaherero pastoralist, Semboyo, 2015). Many Tswana-speaking tribes invested in boreholes leaving the rest reliant on the water from Lake Ngami, which are the majority of the Ovambanderu/Ovaherero pastoralists. During the interviews, most Tswana-speaking tribespeople referred to the Lake as 'lecha la ma Mbanderu' (meaning Lake of the Ovambanderu). Some boreholes were drilled by the government for communal use. Pastoralists also reported that they were provided with free diesel and engine maintenance parts. The development of water resources signified the expansion of usable grazing area in Ngamiland as pastoralists stretched further into the sandveld. However, most of the SLOCA boreholes are now reported to be dysfunctional, as pastoralists reported that '...they were expensive to maintain and most of the water was saline...' (Oral history data, 59-year-old member of the Kareng farmers' committee, Kareng, 2015). The period also coincided with the construction of the southern buffalo fence (Figure 1), a veterinary cordon fence designed to separate cattle from buffaloes for the purpose of controlling the transmission of FMD, so access to the Okavango swamp grazing areas was lost at this time.

\section{The ERA of livestock disease outbreaks 1995: The CBPP epidemic}

In February 1995, an outbreak of contagious bovine pleuropneumonia (CBPP), known as cattle lung disease, occurred in western Ngamiland, with the first cases reported along the Xaudum valley (Figure 1). Respondents reported that this period was the most disturbing period of their lives as pastoralists: '...many families were impoverished and had to rely on government temporary relief programmes...' (Oral history data, 69-year-old Mbanderu pastoralists, Sehithwa, 2015). CBPP is an acute or chronic disease of cattle and wild buffaloes. According to officials at the Department of Veterinary Services (DVS), during the early stages, the disease was confined to the western part of the district. Despite control measures, the disease spread rapidly to the 
east, prompting the government to resort to total eradication by clearing the entire district of cattle. In total, 320,000 cattle were killed of which 114,000 cattle were eradicated from ranches and 206,000 were eradicated from communal lands (DVS 2000). According to respondents, the CBPP caused enormous disruption to the spatial configuration of the pastoral landscape. Following the outbreak, more veterinary fences were introduced. Three major fences were constructed as emergency control measures in 1995 to contain the spread of CBPP: Samochima (Red line fence), Ikoga (Yellow line fence) and Setata (Green line fence) (Raborokgwe 1997) (Figure 1). Pastoralists in the villages of Semboyo and Makakung indicated that the Setata fence changed their land use patterns completely. Livestock movements were curtailed and grazing lands bisected, with some water resources becoming inaccessible. Restocking started in 1997, and by the end of the year, about 70,000 cattle had been reintroduced (DVS 2000). The period also coincided with the implementation of the NPAD fencing component. The policy restated the TGLP assertion that growth in livestock numbers had caused significant overgrazing and degradation and recommended fencing off a large portion of communal lands as commercial private ranches.

Following the declaration of the country as CBPP free, conservation groups, notably the Kalahari Conservation Society (KCS) and local communal pastoralists, convinced the government to demolish the Setata fence. While conservation groups cited environmental concerns, such as blockage of ungulate migratory routes, pastoralists argued that they had been separated from their critical grazing land and water resources. As a result, the Setata fence was decommissioned while the remaining two, the Samochima and Ikoga fences, were declared permanent and incorporated into the Department of Veterinary Service (DVS) Master Plan.

\section{7: Habu FMD outbreak}

In April 2007, an outbreak of FMD was reported at Habu along the Okavango Delta southern buffalo fence. Pastoralists reported that government responded to the outbreak by reconstructing the Setata fence. Cattle in the entire district could not be slaughtered at the Botswana Meat Commission (BMC) abattoirs, which, respondents indicated, resulted in serious financial constraints as they could not pay school fees or have enough to eat. In the process, cattle numbers continued to accumulate in the district. The government set up a relief fund under the National Development Bank (NDB). In this fund, cattle were used as sureties for loans. A farmer could register up to 30 cattle with the Bank at BWP 1,500 (USD 150) per animal on the basis that pastoralists would repay the loans once they started selling to the BMC abattoir. During interviews, some pastoralists claimed that they were being driven into poverty and did not have the means to repay the loans. An interview with NDB staff in Maun revealed that 721 pastoralists used the fund before it was stopped, but so far, only 55 had managed to clear their loans. '...we are owed around BWP 103 million (USD 10.3 million) by Ngamiland pastoralists, there is no market due to the recurrent FMD in the area...' (Expert interview data NDB officer in Maun, 2015).

\section{2: The ranches' protection buffer fence}

The ranches' protection buffer fence (Figure 1) was constructed in 2012 as an emergency measure to prevent FMD from spreading into commercial ranches and Ghanzi District. However, communal pastoralists argued that they never agreed to the creation of the fence on the grounds that it exclusively protects ranchers while cutting communal pastoralists off from their traditional grazing land and water resources. Pastoralists argued that the money used to construct the fence could have been used to maintain the southern buffalo fence which would have solved the problem for all pastoralists. Pastoralists reported that lots of cattle from the communal areas die because they become stranded along the fence while seeking to access traditionally good grazing on the ranches' side. ${ }^{2}$ Interviews with government officials revealed that the fence was not preceded by any impact assessment or feasibility study since it was assumed that it would follow the ranches' boundary.

\section{4: Kareng FMD outbreak}

In April 2014, an outbreak of FMD occurred in Kareng communal lands, an area that has been free from the disease for a long time. It is rare to experience an FMD disease outbreak in the sandveld. According to a veterinary officer, the 2014 outbreak started in Tubu, an area within the swamp, '...that cattle crush and the surrounding cattle posts were surrounded with water following the floods and were inaccessible...so they missed the routine vaccination...' (Expert interview data, veterinary officer, Maun, 2015). However, pastoralists blamed the outbreak on elephants which destroy veterinary fences allowing cattle to cross to the buffalo area or vice versa. Following the outbreak, the Department of Veterinary Services imposed stringent livestock movement protocols on herders. Livestock herding was not allowed except with a permit from the veterinary extension officer, even within the same vaccination area. Pastoralists reported that this resulted in an increase in stray animals, poor herding practices and increased livestock predation as they were not able to conduct routine herding and night kraaling of their animals.

\section{Perspectives on current land use Rangeland access and control}

Respondents reported that they objected to the enclosure by TGLP ranches, mainly on the grounds of reduced 
resource access and restricted mobility. They feared that changes in the structure of the landscape would jeopardise their way of life as a self-sufficient pastoral community. Some informants still recall that they were told during the consultations, a period which they referred to as 'during Seretse Khama', that the ranches would not affect any communal area pastoralists as they would be demarcated in unused land close to the Central Kalahari Game Reserve. However, many respondents argued during focus groups that the land referred to as unused was never there, that in actual fact, these were rangelands that were important to pastoralists for managing periods of excessive drought and disease outbreaks near the delta system and some portions were occupied by the Basarwa ${ }^{3}$ communities. Respondents reported that over the years, ranches have been pushing closer and have encroached further onto communal grazing lands, especially during the implementation of the NPAD ranches: '...the pastoral character of our community has long been lost, so are the ethnic boundaries which distinguished us from the other tribes...' (Interview data, 68-year-old Ovambanderu pastoralist, Bothatogo, 2015). Respondents argued that they wanted to preserve their pastoral identity, maintain the traditional arrangement in which they had regulated access to grazing resources by pastoral communities, and also maintain their territorial integrity.

During focus groups, respondents were critical about government consultation processes, especially the NPAD ranches' allocation process. Many argued that the ranches, which were allocated around cattle posts, did not consider many poor pastoralists who did not have boreholes but depended on the communal areas and the numerous sandveld natural water pans for survival. As respondents stressed: '...government officials came to the kgotla (traditional gathering place) and told the community that those with boreholes will be allocated ranches, the community agreed because they didn't know what that meant...some people had just borehole points and those were treated as boreholes and were allocated ranches...' (Focus group discussion data, Toteng, 2015)

A few respondents reported that they tried applying for ranches, but the allocation process and requirements were beyond their comprehension so the majority of those ranches were given to outsiders or those with financial resources: '...also, business proposals and management plans are demanded from us, overriding the practical experience we have as pastoralists ...' (Focus group discussion data, Toteng, 2015), 'I tried to apply for an NPAD ranch and I think my ranch management plan was comprehensive enough...but still, the land board turned down my application...' (Youth focus group discussion data, Sehithwa, 2015).

The allocation process for the ranches is a complex process for communal area pastoralists, especially those without boreholes. First, the Land Board requires an applicant to show proof of financial resources in excess of BWP 250,000 (USD 25,000) to develop the ranch if allocated (TLB 2015). 'The applicant is also expected to demonstrate through a business or ranch management plan a thorough knowledge of the ranching management processes; paddocking, rotational grazing, fire management, water development and disease management ...' (Expert interview data, Maun, 2015). Such requirements exclude poor communal area farmers from competing with those with financial resources. Moreover, most of the business plans and management plans submitted for ranch applications are prepared by consultants (Ntingana 2007). This means that the understanding of the commercial ranch management strategies demonstrated in the management plan is a theoretical understanding by the consultant and not the applicant. The majority of the communal area pastoralists do not have financial resources to hire a consultant to write management plans for them. The allocation system is such that it gives those who previously had only de facto rights to grazing around their boreholes exclusive rights to previously communal grazing lands (RoB 1991). The large costs of drilling and equipping a borehole ensures that owning a borehole remains a privilege of the wealthier.

\section{Wildlife conservation versus traditional livelihoods}

One of the pertinent issues in the area is human-wildlife conflict, especially with elephants, which respondents argued is the major contributing factor to the rampant FMD. Most of the respondents complained about the ever-increasing elephant and buffalo populations: 'It is not fair that as Ngamiland farmers we continue being impoverished by these increasing buffalo and elephant population...if the government cannot help us, they should allow these animals to move to other parts of the country...' (Focus group discussion data, a member of Ngamiland Integrated Farmers' Association, Sehithwa, 2015). Buffaloes are considered to be the carrier of FMD. Elephants extend their range into cattle post areas and arable lands, damaging livestock water resources and veterinary fences that separate cattle from buffaloes.

Respondents appeared to be critical about the way government departments are handling the FMD epidemic. The Department of Wildlife and National Parks is criticised for failing to control the movement of elephants which continue to destroy veterinary cordon fences on a daily basis: '...the attitude of authorities when dealing with the control and containment of FMD is worrisome...there is no maintenance of the buffalo fence. We have long called for the electrification of that fence but up to now nothing is happening...' (Focus group discussion data, a member of the farmer's committee, Kareng, 2015). Government officials acknowledged that efforts to 
mitigate the conflict at the interface between elephants and shrinking rangelands have met with limited success. However, others still blamed pastoralists for their reluctance to help the government to contain the problem: '....frequent damage of the buffalo fence by elephants presents our greatest challenge in confronting the FMD scourge. We continue trying...but at the same time ask for maximum cooperation from pastoralists... others are reluctant, we urge them to do their part by stopping their cattle from moving closer to the buffalo fence ...' (Interview data, veterinary officer, Maun, 2015).

\section{Increased vulnerability and poverty due to loss of resource access}

Vulnerability denotes pastoralists' lack of resilience to the occurrences of uncertain events: droughts, livestock diseases, exclusion from markets, resource scarcity in the form of marginalised access or rangeland degradation (Rass 2006). Historical narratives suggest that people living on the fringes of the Okavango Delta have experienced difficulties over a long period of time. Risks range from diminishing communal grazing lands, drought, livestock diseases, predation, conflicting land uses, floods and destruction of crops by animals. The FMD epidemic and the enclosure of the formerly wet season grazing pastures and water resources continue to undermine the livelihood of the Ovambanderu and Ovaherero, with communities reporting that many impoverished young men and women are being forced into seeking employment in town or the government labour-intensive public works (Ipelegeng) programme: '... We now depend on government hand-outs for survival because the land is not enough for sustainable pastoral farming and there are no markets for livestock products...' (Focus group discussion data, Toteng, 2015).

Some respondents reported that they used to diversify their income sources by working off-farm, selling fuelwood, logs, thatching grass and wild berries. This is no longer the case as all these are now enclosed by the ranches' protection buffer fence: 'I used to cut logs, droppers (wood spacers), thatching grass and gather wild berries in there and sell, now my business has collapsed because all these resources are now on private land...we can't even go near that fence because we are afraid of the soldiers...' (Oral history data, 68-year-old pastoralist, Bothatogo, 2015).

The persistently high stocking pressures in communal areas especially around Lake Ngami are driven not only by large numbers of animals but also by the effects of a shrinking land base. As pressure on land increases, the pastoralists' mode of subsistence is left in a situation of worsening vulnerability. Discussions in focus groups and subsequent expert interviews both stressed that the effect of overgrazing between the ranches' protection fence and Lake Ngami has significantly reduced both the grass cover density and biodiversity of the area.
Bare soils and a significant presence of invasive species such as of Acacia mellifera were observed, and some areas were choked with bushes. Congestion in communal areas has also made it difficult to control the spread of FMD.

Expert interviews and focus groups revealed that the exclusion from livestock markets has resulted in part-time and town-dwelling livestock owners. This has resulted in neglected livestock near major settlements, roads, rivers and the Lake, including lots of stray animals. Some respondents argue that this is also a major contributing factor in the spread of livestock diseases since these stray animals are never vaccinated. Citing the destruction of their cattleled lifestyle, and land use policies which pastoralists argued favours mainly two types of land use (wildlife and commercial ranching), some Ovaherero pastoralists expressed their desire to abandon Ngamiland and repatriate to their native Namibia: '....I haven't been able to sell since 2007, the land has seriously diminished since the erection of that fence (the ranches protection buffer fence)...BMC buys only from the ranches, we poor pastoralists are in the dark. I think it's meaningful to go back to Namibia...' (Oral history data, 65year-old Ovaherero pastoralist, Makakung, 2015).

\section{Discussion}

\section{Flexible mobility and land tenure transformation}

Understanding how pastoral landscapes have changed over time in response to a range of influences is essential for planning and policy development and can promote a clearer understanding of likely future changes in pastoral landscapes (Cousins et al. 2007). Adaptation and response strategies must be grounded in pastoralists' historical experience and knowledge (Ericksen et al. 2013). Pastoralists have a deep knowledge and understanding of their environment and have developed grazing practices and adaptation strategies which are consistent with their environment and socio-cultural context (Basupi et al. 2017). Ngamiland pastoralists have customarily used risk-spreading tactics over the years; these include strategic movement of livestock away from disease-prone environs such as the Okavango Delta Swamps, so as to access pasture resources and water in sandveld pans after rains, as well as herd splitting to take advantage of the varied and uncertain environmental conditions.

Dryland pastoralists rely on the demonstrated coping strategy of mobility in order to respond to environmental variability and occurrence of uncertain events such as droughts (Fernandez-Gimenez and Le Febre 2006; Ellis 1995). Mobility allows strategic access to scarce and scattered rangelands resources: water and pasture (Vetter 2005; Kaye-Zwiebel and King 2014). In Ngamiland, the de facto privatisation of communal rangelands did not take into consideration this effective strategy of extracting value out of these marginal lands. Botswana's rangeland policy was developed because of the perceived overstocking, 
degradation and the negative stigma associated with opportunistic pastoralism especially in the eastern hardveld communal rangelands (Rohde et al. 2006; White 1993). The severe droughts in the 1960s/1980s seem to have strengthened the communal rangeland crisis narrative, resulting in the conclusion by government that rangelands are in crises and in need of an intervention. This gave impetus to rangeland enclosure and privatisation through TGLP. The process of rangeland tenure transformation is changing the patterns of resource tenure and access, reinforcing the dominant patterns of winners and losers in the communal areas (Tache 2013; Cullis and Watson 2005). The use of boreholes as a mechanism in ranch allocation effectively meant that grazing land is allocated de facto to an elite of cattle owners who have acquired exclusive use of the land by making the necessary investment in borehole drilling and water reticulation (Perkins 1996; White 1993). In Ngamiland, resource-poor pastoralists who could not afford to invest in borehole drilling subsequently lost the opportunity to capture private land. The ensuing scenario is one in which pastoralists are squeezed between fences (Basupi et al. 2017), their resilience to climatic shocks and diseases has been significantly weakened and problems of congestion and land use conflicts could lead to the very problems of rangeland degradation that these policies and strategies were purported to prevent.

\section{Policy and institutional lessons}

Historical perspectives recounted by local pastoralists provide important insights into key events and changes in an area. In Ngamiland, livestock disease outbreak emerges as a key theme. FMD outbreaks have occurred with increasing frequency in recent years. Livestock owners appear to be less observant of animal health issues than was previously the case. A strategy is suggested which emphasises getting the general conditions right for livestock owners to make the necessary commitment and investment in the fight against the disease, in a manner suitable to the local condition and context. In Ngamiland, pastoralists' seasonal movements served as a means of controlling grazing lands, preventing out-ofseason grazing and managing livestock diseases and humanwildlife conflicts. Although the allocation of rangeland resources previously existed, especially between villages and clans around important historical natural water pans, customary enforcement of movement patterns by village chiefs was an effective means of managing rangelands and livestock. These movements also provided pastoralists with secure access rights to key grazing resources, especially in periods of scarcity such as during dry or drought periods. These traditional livestock management institutions have been significantly altered by rangeland transformations. The centralisation of land resource management has meant that a complex network of sectoral institutions is used to manage communal lands, excluding the pastoralists and their leaders, thus rendering them losers in the process (Cullis and Watson 2005; Peters 1994). Pastoralists' resilience to climate shocks and uncertainties has been weakened as a result. The new pastoral environment means that pastoralists' vulnerability is increasing even to slight variations and intensity of rainfall (Letai and Lind 2013). Technocratic approaches to policy-making neglect local communities' experiences in formulating rangeland policies (Rennie 1998), resulting in strategies that fail to address the root cause of the problem.

\section{Conclusions}

This study proposes a strong consideration of historical perspectives in informing policy debates on sustainable pastoralism. Understanding the management of rangelands through pastoralism has substantial policy relevance and can help structure possible entry points for sustainable land management initiatives. Findings show that for pastoral social-ecological systems in Ngamiland, the trajectories of change can be outlined within four themes: Ovambanderu/ Ovaherero historical land use practices, disease outbreaks, climate variability and land tenure transformation facilitated through expansion in borehole technology and national rangeland policies. The effect of communal land tenure transformation on SLM and pastoralists' adaptive capacity requires understanding complex social-ecological systems and developing more appropriate and locally relevant strategies.

From experiences of the past, lessons can be drawn of the sort of practices, processes and institutions required for pastoralism policies and/or planned pastoralists' adaptations. In Ngamiland, historical narratives suggest a high level of human-wildlife conflict that even a double fence will do little to stop. Pastoralists' attitudes towards wildlife are negative as they feel that wild animals are responsible for their distresses such as livestock diseases. Working with pastoralists could act to protect their lifestyles as pastoralists while ensuring wildlife conservation. There is need for institutional diversity in order to maintain any part of the system. Using pastoralists to provide services, particularly in the area of indigenous knowledge, interlocking strategies can be developed to link conservation of wildlife and rangelands with pastoral production by developing ecologically sensitive low-volume tourism that pastoral communities can tap in to diversify their livelihoods. For example, community-managed game farming around the periphery of the Delta along the southern buffalo fence would form a protective buffer against FMD while generating income opportunities for pastoral communities.

Throughout the study villages, the relationship between pastoralists and government officials when it comes to 
either containment of FMD, elephants-related conflicts or control and access to rangeland resources came close to institutionalised mistrust. Dealing with a complex socialecological system requires that government do more than pay lip service to the concept of consultation and participation. While governments have access to information on climate or disease, pastoralists can provide a compact account of local conditions based on years of practical experience, thus enabling a more appropriate and locally relevant policy environment. In this process, historical perspectives can form a point of reference by which institutions perceive issues, assess scientific findings and justify decisions. In Botswana, relatively little effort has been made to integrate historical perspectives into land use planning. Past attempts to support pastoral development have failed to successfully balance the needs of critical ecological pastoral areas through appropriate policy and technical approaches. Progress from here will depend not so much on the pastoralists but on the willingness of government agencies responsible for policy to talk to people through genuine participation.

\section{Endnotes}

${ }^{1}$ Mafisa is a traditional practice which is similar across most Tswana tribes, entitling the loan of cattle to a borrower, who in exchange for herding is entitled to the milk and to use the cattle as draft power, as well as keeping some of the offspring of the herded cattle (Parson 1981).

${ }^{2}$ Most ranches are unfenced; before the ranches' protection buffer fence was constructed, cattle could roam freely and thus utilised numerous pans for grazing and watering on the ranches' side.

${ }^{3}$ Basarwa, also known as the San people or Bushmen, are indigenous former nomadic people occupying the Kalahari Desert and adjacent areas in Botswana. Basarwa are known to live in some of the most inhospitable terrains surviving by hunting wild game, gathering roots, tubers and wild fruits. Today the land that Basarwa used to hunt on is increasingly being taken up for grazing, commercial ranching, game reserves and national parks. They predominate among the Remote Area Dweller (RAD) groups.

${ }^{4}$ Remote Area Dweller (RAD) settlements are settlements established under the government of Botswana's Remote Area Development Programme (RADP). The programme targets socially and economically marginalised populations living outside main villages. People living in RAD settlements are out of reach in terms of distance from generally available services such as education, health and have no real access to land or adequate water rights. They are normally assisted with food, clothing, children's transportation to school and some income generating activities to address rural poverty.

\section{Abbreviations}

CBPP: Contagious bovine pleuropneumonia; CKGR: Central Kalahari Game Reserve; FMD: Foot and mouth disease; NPAD: National Policy on Agricultural Development; SLM: Sustainable land management; SLOCA: Services to Livestock Owners in Communal Areas; TGLP: Tribal Grazing Land Policy

\section{Acknowledgements}

This research was supported by funding from the Government of Botswana, the Botswana International University of Science and Technology and the University of Leeds Sustainable Agriculture Fund Bursary. Funds for publication of this paper were provided by the Centre for Climate Change Economics and Policy, University of Leeds. The study was carried out under the Government of Botswana research permit number EWT 8/36/4 XXX (73). We thank the Ngamiland pastoral communities for sharing their opinions and for their active participation in the research. Many thanks to the anonymous reviewers for their insightful comments and suggestions. Thanks to Dr. Susannah Sallu for the insightful feedback on an earlier draft of this manuscript.

\section{Authors' contributions}

LVB, the first author, was involved in the whole process of research design, data collection, data analysis and interpretation as well as drafting the manuscript. CHQ and AJD, as the supervision team, provided substantial inputs throughout the process from design, data collection, analysis and interpretation and manuscript writing. All authors read and approved the final manuscript to be published.

\section{Competing interests}

The authors declare that they have no competing interests.

\section{Publisher's Note}

Springer Nature remains neutral with regard to jurisdictional claims in published maps and institutional affiliations.

Received: 2 February 2017 Accepted: 31 May 2017

Published online: 23 August 2017

\section{References}

Adam, YO, J Pretzsch, and D Darr. 2015. Land use conflicts in central Sudan: Perception and local coping mechanisms. Land Use Policy 42: 1-6. Adriansen, HK, and TT Nielsen. 2002. Going where the grass is greener: On the study of pastoral mobility in Ferlo, Senegal. Human Ecology 30: 215-226.

Almagor, U. 1980. Pastoral identity and reluctance to change: The Mbanderu of Ngamiland. Journal of African Law 24: 35-61.

Basupi, LV, CH Quinn, and AJ Dougill. 2017. Using participatory mapping and a participatory geographic information system in pastoral land use investigation: Impacts of rangeland policy in Botswana. Land Use Policy 64: 363-373.

Behnke, RH. 1987. Cattle accumulation and the commercialization of the traditional livestock industry in Botswana. Agricultural Systems 24: 1-29.

Brottem, L, MD Turner, B Butt, and A Singh. 2014. Biophysical variability and pastoral rights to resources: West African transhumance revisited. Human Ecology 42: 351-365.

Cousins, B, MT Hoffman, N Allsopp, and RF Rohde. 2007. A synthesis of sociological and biological perspectives on sustainable land use in Namaqualand. Journal of Arid Environments 70: 834-846.

Cullis, A, and T Watson. 2005. Winners and losers: Privatising the commons in Botswana. Colchester: Willprint.

DOL. 2009. Department of Lands (DoL). Ngamiland integrated land use plan, final report. Botswana: Ministry of Lands and Housing.

Dougill, AJ, DSG Thomas, and AL Heathwaite. 1999. Environmental change in the Kalahari: Integrated land degradation studies for nonequilibrium dryland environments. Annals of the Association of American Geographers 89: 420-442.

DVS. 2000. Livestock report: CBPP, destocking and restocking. Maun, Botswana: Department of Veterinary Services.

Dziewiecka, M. 2008. Place of people: The Khwebe Hills in the history of Ngamiland. Botswana Notes and Records 40: 11-20.

Ellis, JE. 1995. Climate variability and complex system dynamics: Implications for pastoral development. In Living with uncertainty: New directions in pastoral development in Africa, ed. I Scoones, 37-46. Exeter: Intermediate Technology Publications. 
Ellis, J. E. \& Swift, D. M. 1988. Stability of African pastoral ecosystems: Alternate paradigms and implications for development. Journal of Range Management 41: 450-459.

Ericksen, P, JD Leeuw, P Thornton, M Said, M Herrero, and A Notenbaert. 2013. Climate change in sub-Saharan Africa: What consequences for pastoralism. In Pastoralism and Development in Africa: Dynamic Change at the Margins, Pathways to sustainability, ed. A Catley, J Lind, and I Scoones, 71-81. New York: Routledge.

Fernandez-Gimenez, ME. 2006. Land use and land tenure in Mongolia: A brief history and current issues. In USDA Forest Service Proceedings, RMRS-P-39, 30-36.

Fernandez-Gimenez, ME, and S Le Febre. 2006. Mobility in pastoral systems: Dynamic flux or downward trend? International Journal of Sustainable Development \& World Ecology 13: 341-362.

Fratkin, E. 1997. Pastoralism: Governance and development issues. Annual Review of Anthropology 26: 235-261.

Gale, NK, G Heath, E Cameron, S Rashid, and S Redwood. 2013. Using the framework method for the analysis of qualitative data in multi-disciplinary health research. BMC Medical Research Methodology 13: 117-117.

Gewald, J. 2002. I was afraid of Samuel, therefore I came to Sekgoma: Herero refugees and patronage politics in Ngamiland, Bechuanaland protectorate, 1890-1994. Journal of African History 43: 211-234.

Kaye-Zwiebel, E. \& King, E. 2014. Kenyan pastoralist societies in transition: Varying perceptions of the value of ecosystem services. Ecology and Society 19: 17-35.

Kitchell, E, MD Turner, and JG McPeak. 2014. Mapping of pastoral corridors: Practices and politics in eastern Senegal. Pastoralism 4: 1-14.

Letai, J, and J Lind. 2013. Squeezed from all sides: Changing resource tenure and pastoralist innovation on the Laikipia Plateau, Kenya. In Pastoralism and Development in Africa: Dynamic Change at the Margins, ed. A Catley, J Lind. and I Scoones, 164-176. New York: Routledge.

Magole, L. 2009. The 'shrinking commons' in the Lake Ngami grasslands, Botswana: The impact of national rangeland policy. Development Southern Africa 26: 611-626.

McGahey, D. 2011. Livestock mobility and animal health policy in southern Africa: The impact of veterinary cordon fences on pastoralists. Pastoralism 1: 1-29.

Miller-Rosser, K, Y Chapman, and K Francis. 2009. Analysing oral history: A new approach when linking method to methodology. International Journal of Nursing 15: 475-480.

Moritz, M, B Larisa Catherine, A Drent, S Kari, A Mouhaman, and P Scholte. 2013. Rangeland governance in an open system: Protecting transhumance corridors in the Far North Province of Cameroon. Pastoralism 3: 1-10.

Mwangi, E. 2009. Property rights and governance of Africa's rangelands: A policy overview. Natural Resources Forum 33: 160-170.

Notenbaert, A, J Davies, J de Leeuw, M Said, M Herrero, P Manzano, M Waithaka, A Aboud, and S Omondi. 2012. Policies in support of pastoralism and biodiversity in the heterogeneous drylands of East Africa. Pastoralism 2: 1-17.

Ntingana, T. 2007. Consultant fault? Boreholes and the fencing policy in Ngamiland: A discussion paper. Sustainable Land Management Workshop. Maun, Botswana: Tawana Land Board.

Oba, G. 2013. The sustainability of pastoral production in Africa. In Pastoralism and Development in Africa: Dynamic Change at the Margins, Pathways to Sustainability, ed. A Catley, J Lind., and I Scoones, 29-36. New York: Routlege.

Parson, J. 1981. Cattle, Class and the state in rural Botswana. Journal of Southern African studies 7:236-255.

Patton, MQ. 1990. Qualitative evaluation and research methods. Newbury: Sage Publications Inc.

Perkins, JS. 1996. Botswana: Fencing out the equity issue. Cattleposts and cattle ranching in the Kalahari Desert. Journal of Arid Environments 33: 503-517.

Peters, PE. 1994. Dividing the commons: Politics, policy, and culture in Botswana. Charlottesville: University of Virginia.

Raborokgwe, MV. 1997. Cordon fences and wildlife issues. In Proceedings of a National Confrence on conservation and management of wildlife in Botswana: Strategies for the twenty first century, 13th - 17th October 1997, ed. F. Monggae, 114-120.

Rass, N. 2006. Policies and strategies to address the vulnerability of pastoralists in sub-Saharan Africa. In FAO Pro-poor Livestock Policy Initiative. Rome: FAO. Working paper No 37

Rennie, R. 1998. History and policy-making. The social science sphere. Oxford: Blackwell Publishers.
ROB. 1975. Republic of Botswana, National Policy on Tribal Grazing Land: Government Paper no. 2 of 1975. Gaborone: Government Printers.

ROB. 1991. Republic of Botswana, National Policy on Agricultural Development (NPAD). Gaborone: Government Printers.

Rohde, RF, NM Moleele, M Mphale, N Allsopp, R Chanda, MT Hoffman, L Magole, and E Young. 2006. Dynamics of grazing policy and practice: Environmental and social impacts in three communal areas of southern Africa. Environmental Science \& Policy 9: 302-316.

Scoones, I (ed.). 1995. Living with uncertainty. New directions in pastoral development in Africa. London: Intermediate Technology Publications.

Swetnam, TW, CD Allen, and JL Betancourt. 1999. Applied historical ecology: Using the past to manage for the future. Ecological Applications 9: 1189-1206.

Swift, J. 1991. Local customary institutions as the basis for natural-resource management among Boran pastoralists in Northern Kenya. In IDS BulletinInstitute of Development Studies, vol. 22, 34-37. Brighton: Institute of Development Studies.

Tache, B. 2013. Rangeland enclosures in Southern Oromia, Ethiopia: An innovative response or the erosion of common property resources? In Pastoralism and Development in Africa: Dynamic Change at the Margins, Pathways to Sustainability, ed. A Catley, J Lind., and I Scoones, 37-46. New York: Routlege.

TLB. 2015. Tawana Land Board, allocation guidelines for ranches and other commercial plots. Maun, Botswana: Ministry of Lands and Housing.

Tlou, T. 1985. A history of Ngamiland: The formation of an African State. Gaborone: Macmillan Publishers.

Vetter, S. 2005. Rangelands at equilibrium and non-equilibrium: Recent developments in the debate. Journal of Arid Environments 62: 321-341.

White, R. 1993. Livestock development and pastoral development in Botswana. Botswana Society 25: 187-190

\section{Submit your manuscript to a SpringerOpen ${ }^{\circ}$ journal and benefit from:}

- Convenient online submission

- Rigorous peer review

- Open access: articles freely available online

- High visibility within the field

Retaining the copyright to your article

Submit your next manuscript at $>$ springeropen.com 